\title{
PENERAPAN PEMBELAJARAN TEMATIK BERWAWASAN MULTIPLE INTELLEGENCE DALAM UPAYA MEMBENTUK KARAKTER SISWA DI SD IT AL ISLAM KUDUS
}

\author{
*Fina Fakhriyah, *Mila Roysa, *Sumaji, \\ Program Studi Pendidikan Guru Sekolah Dasar \\ Email: phienaim16@gmail.com
}

\begin{abstract}
The purpose of this research were (1) to describe the application of thematic learning insightful multiple intellegence in order to form the students character from SD IT Al Islam Kudus, (2) to determine the effect of insightful thematic learning from SD IT Al Islam Kudus. This research is true experimental pretest-postest with a randomized control group design. The results show the positive influence as a result of implementing multiple intellegence insightful thematic learning on learning outcomes and student character. Average learning outcomes experimental group was higher than the control group. Students also feel happy because learning is done in accordance with the intellegence they have. The characters involved in this study include established democratic character, curiosity, independence and responsibility.
\end{abstract}

\begin{abstract}
ABSTRAK
Penelitian ini bertujuan untuk (1) mendeskripsikan penerapan pembelajaran tematik berwawasan multiple intellegence dalam upaya membentuk karakter siswa SD IT Al Islam Kudus, (2) mengetahui pengaruh pembelajaran tematik berwawasan multiple intellegence siswa SD Islam Terpadu Al Islam Kudus. Penelitian ini merupakan penelitian true experimental dengan randomized pretest-postest control group design. Hasil penelitian menunjukkan adanya pengaruh positif sebagai dampak mengimplementasikan pembelajaran tematik berwawasan multiple intellegence terhadap hasil belajar dan karakter siswa. Rata-rata hasil belajar kelompok eksperimen lebih tinggi daripada kelompok kontrol. Siswa juga merasa senang karena pembelajaran yang dilakukan sesuai dengan kecerdasan yang mereka miliki. Karakter yang ikut terbentuk dalam pembelajaran ini meliputi karakter demokratis, rasa ingin tahu, mandiri dan tanggung jawab.
\end{abstract}

Kata Kunci: Multiple Intellegence, Pendidikan Karakter, Pembelajaran Tematik.

\section{PENDAHULUAN}

Pendidikan diartikan sebagai proses reorganisasi dan rekonstruksi pengalaman sehingga dapat menambah efisiensi individu dalam interaksinya dengan lingkungan. Kesadaran akan pentingnya pendidikan kini cenderung meningkat. Pendidikan secara universal dapat dipahami sebagai upaya pengembangan potensi kemanusiaan secara utuh dan penanaman nilai-nilai sosial budaya yang diyakini oleh sekelompok masyarakat agar dapat mempertahankan hidup dan kehidupan 
secara layak. Mengingat akan Kegiatan pembelajaran tematik pentingnya pendidikan, maka dirancang dengan tema sebagai wadah pemerintah mencanangkan program mengenalkan berbagai konsep untuk wajib belajar 9 tahun, melakukan mengenal dirinya dan lingkungan perubahan kurikulum untuk mencoba sekitarnya. Tema dipilih dan mengakomodasikan kebutuhan siswa.

Berdasarkan fungsi dan tujuan pendidikan nasional, jelas bahwa pendidikan di setiap jenjang, mulai pendidikan dasar hingga pendidikan tinggi, harus dirancang dan diselenggarakan secara sistematis guna mencapai tujuan tersebut. Dalam rangka pembentukan karakter peserta didik sehingga beragama, beretika, bermoral, dan sopan santun dalam berinteraksi harus dipersiapkan dan dilaksanakan.

Selain pendidikan karakter, perkembangan anak merupakan salah satu sasaran utama dalam kegiatan pendidikan atau pembelajaran pada berbagai satuan, jenis, dan jenjang pendidikan. Dalam pelaksanaan kegiatan pendidikan harus diperhatikan berbagai aspek, tahapan, dan karakteristik perkembangan anak menjadi subjek didik. Perkembangan anak pada berbagai dimensi perkembangan tidak pernah terlepas dari konteks kehidupan sosial dan kultural yang melatarbelakanginya. Anak-anak memiliki berbagai kebutuhan mulai dari kebutuhan dasar sampai kebutuhan lanjut, sebagaimana diungkapkan dalam teori Maslow, bahwa anak-anak yang berangkat ke sekolah dalam kondisi kenyang, cukup tidur, dan istirahat, serta batin yang senang menunjukkan motivasi belajar yang tinggi, aktif, dan ceria.

Perkembangan anak bersifat sistematis, progresif, dan berkesinambungan. Hal ini berarti kemajuan perkembangan satu aspek akan mempengaruhi aspek perkembangan lainnya. Oleh karena itu, diperlukan pembelajaran yang dapat menstimulus perkembangan pendidikan anak yaitu dengan pembelajaran tematik. dikembangkan dari hal-hal yang paling dekat dengan anak, sederhana, serta menarik minat.

Pembelajaran tematik adalah pembelajaran terpadu yang menggunakan tema untuk mengaitkan beberapa mata pelajaran sehingga dapat memberikan pengalaman belajar yang bermakna kepada peserta didik (Depdiknas, 2006). Jadi dalam pembelajaran tematik seorang guru harus kreatif dalam menyampaikan pembelajaran tematik karena terdiri atas berbagai mata pelajaran yang nantinya siswa dapat mengembangkan kemampuannya dalam mengolah kreativitasnya dalam belajar agar menjadi lebih bermakna dan dapat mengasah kecerdasan anak. Akan tetapi, Mulyadi (dalam Susanto, 2003) seorang praktisi pendidikan anak, bahwa suatu kekeliruan yang besar jika setiap kenaikan kelas, prestasi anak didik hanya diukur dari kemampuan matematika dan bahasa. Dengan demikian sistem pendidikan nasional mengukur tingkat kecerdasan anak didik yang semata-mata hanya menekankan kemampuan logika dan bahasa perlu direvisi.

Pembelajaran tematik merupakan pembelajaran yang dirancang berdasarkan tema-tema tertentu. Sebagai contoh, tema "diri sendiri" dapat ditinjau dari mata pelajaran IPA, IPS, Bahasa Indonesia dan Matematika. Menurut Trianto (2011) Pembelajaran tematik menyediakan keluasan dan kedalaman implementasi kurikulum, menawarkan kesempatan yang sangat banyak pada siswa untuk memunculkan dinamika dalam pendidikan. Sedangkan menurut Sutirjo dan Sri Istuti Mamik (2004) 
menyatakan bahwa pembelajaran tematik merupakan salah satu usaha untuk mengintegrasikan pengetahuan, keterampilan, nilai, atau sikap pembelajaran, serta pemikiran yang kreatif dengan menggunakan tema. Dari dua pendapat diatas, peneliti dapat mempertegas bahwa pembelajaran tematik dilakukan dengan maksud sebagai upaya untuk memperbaiki dan meningkatkan kualitas pendidikan, terutama untuk mengimbangi padatnya materi kurikulum, serta menyesuaikan dengan tingkat perkembangan anak dan kecerdasan yang dimiliki oleh anak, karena pada umur dibawah 9 tahun anak belum bisa memisahkan secara terinci apa yang telah dipelajarinya.

$$
\text { Beberapa }
$$

keuntungan

pembelajaran tematik yaitu: a) siswa mudah memusatkan perhatian pada suatu tema tertentu; b) siswa mampu mempelajari pengetahuan dan mengembangkan berbagai kompetensi dasar antar mata pelajaran dalam tema yang sama; c) pemahaman terhadap materi pelajaran lebih mendalam dan berkesan; d) kompetensi dasar dapat dikembangkan lebih baik dengan mengkaitkan mata pelajaran lain dengan pengalaman pribadi siswa; e) Siswa mampu lebih merasakan manfaat dan makna belajar karena materi disajikan dalam konteks tema yang jelas; f) Siswa lebih bergairah belajar karena dapat berkomunikasi dalam situasi nyata; g) guru dapat menghemat waktu karena mata pelajaran yang disajikan dapat dipersiapkan sekaligus.

Kecerdasan intelektual tidak hanya mencakup dua parameter, yaitu matematika dan bahasa, akan tetapi juga harus dilihat dari aspek kinetis, musical, visual-spasial, intrapersonal, dan naturalis. Jenis kecerdasan intelektual tersebut dikenal dengan sebutan kecerdasan jamak (Multiple Intellegence) yang diperkenalkan oleh
Howard Gadner tahun 1983. Teori Multiple Intellegence yang menyatakan bahwa kecerdasan meliputi delapan kemampuan intelektual. Teori tersebut didasarkan pada pemikiran bahwa kemampuan intelektual yang diukur melalui tes IQ sangatlah terbatas karena tes IQ hanya menekan pada kemampuan logika matematika dan bahasa (Gadner, 2006). Akan tetapi, setiap orang mempunyai cara yang unik untuk menyelesaikan persoalan yang dihadapinya. Kecerdasan bukan hanya dilihat dari nilai yang diperoleh seseorang. Kecerdasan merupakan kemampuan yang dimiliki oleh seseorang untuk melihat suatu masalah, lalu menyelesaikan masalah tersebut atau membuat sesuatu yang dapat berguna bagi orang lain. Menurut pendapat Sugiharti (2005) melalui penerapan metode mengajar yang kreatif dan aplikatif berdasarkan multiple intellegence yang dimiliki anak-anak pembelajaran yang mulanya menakutkan menjadi menyenangkan dan dapat meningkatkan aktivitas siswa.

Istilah multiple intellegence pertama kali dikemukan oleh Howard Gardner. Gardner berusaha memperluas lingkup potensi manusia melampaui batas-batas skor IQ. Gardner juga menyatakan bahwa kecerdasan berkaitan dengan kapasitas/kemampuan untuk (1) memecahkan masalah-masalah dan (2) menciptakan produk-produk dan karyakarya dalam sebuah konteks yang kaya dengan keadaan yang naturalistik (Amstrong, 2013). Psikolog Gardner (2006) menyediakan sarana untuk memetakan berbagai kemampuan siswa dengan mengelompokkan kemampuankemampuan mereka dalam delapan kecerdasan yaitu: kecerdasan linguistik, kecerdasan logis-matematis, kecerdasan visual-spasial, kecerdasan kinestetikjasmani, kecerdasan musikal, kecerdasan 
interpersonal, kecerdasan intrapersonal dan kecerdasan naturalis.

Tujuan dalam penelitian ini yaitu untuk mengetahui penerapan pembelajaran tematik berwawasan multiple intellegence dalam upaya membentuk karakter siswa kelas I SD Islam Terpadu Al Islam Kudus dan untuk mengetahui pengaruh pembelajaran tematik berwawasan multiple intellegence dalam upaya membentuk karakter siswa kelas I SD Islam Terpadu Al Islam Kudus terhadap hasil belajar siswa.

\section{METODE PENELITIAN}

Penelitian ini merupakan penelitian true experimental dengan randomized pretest-postest control group design. Penelitian ini dilaksanakan di SD Islam Terpadu Al Islam Kudus pada bulan September sampai Oktober 2013. Dengan populasi seluruh siswa kelas 1 SD IT Al Islam Kudus tahun ajaran 2013/2014 sebnayak 5 kelas. Sampel adalah bagian dari populasi yang dapat dianggap mewakili dan mencerminkan keadaan populasi (Sukamadinata, 2005). Prosedur pengambilan sampel pada penelitian ini adalah secara random sampling. Kelas yang digunakan untuk penelitian sebanyak 2 kelas. Satu kelas sebagai kelas eksperimen (pembelajaran tematik dengan wawasan multiple intellegence) dan satu kelas yang lain sebagai kelas kontrol (pembelajaran konvensional). Pengambilan sampel dilakukan setelah populasi memenuhi syarat homogen. Sebelum dilakukan uji homogenitas, data yang diuji harus berdistribusi normal. Data yang digunakan untuk uji homogenitas dan normalitas adalah nilai ulangan harian pada tema sebelumnya.

Variabel bebas dalam penelitian ini yaitu penerapan pembelajaran tematik berwawasan multiple intellegence, sedangkan variabel terikatnya yaitu hasil belajar dan pembentukan karakter siswa pada tema kegiatanku tahun ajaran 2013/2014.

Jenis penelitian ini adalah true experimental dengan menggunakan randomized pretest-posttest control group design yang dapat divisualisasikan pada Tabel. 1.

Tabel. 1 Randomized PretestPosttest Control Group Design

$\begin{array}{lccc}\text { Kelompok } & \begin{array}{c}\text { Pretes } \\ \boldsymbol{t}\end{array} & \begin{array}{c}\text { Perlaku- } \\ \text { an }\end{array} & \text { Posttest } \\ \begin{array}{l}\text { Acak A } \\ \text { (kelas }\end{array} & \mathrm{V} & \mathrm{V} & \mathrm{V} \\ \text { eksperimen) } & & & \\ \begin{array}{l}\text { Acak B } \\ \text { (kelas }\end{array} & \mathrm{V} & - & \mathrm{V} \\ \text { kontrol) } & & & \end{array}$

Kelompok A maupun B memiliki karakteristik yang sama atau homogen, karena diambil atau dibentuk secara acak (random) dari populasi yang homogen pula. Dalam desain ini kedua kelompok diberi tes awal (pretest) dengan tes yang sama. Kemudian kelompok A sebagai kelompok eksperimen diberi perlakuan yaitu pembelajaran tematik berwawasan multiple intellegence dengan penekanan pada karakter siswa, sedang kelompok B diberi perlakuan seperti biasa (pembelajaran langsung yang biasa diterapkan oleh guru). Kemudian kedua kelompok dites dengan tes yang sama sebagai tes akhir (posttest). Hasil kedua tes akhir dibandingkan (diuji perbedaannya), demikian juga antara hasil tes awal dengan tes akhir pada masing-masing kelompok.Perbedaan yang berarti (signifikan) antara kedua hasil tes akhir, dan antara tes awal dan akhir pada kelompok eksperimen menunjukkan pengaruh dari perlakuan yang diberikan. Selama proses pembelajaran berlangsung, observer melakukan pengamatan terhadap hasil belajar dan karakter siswa.

Hipotesis penelitian ini adalah adanya pengaruh penerapan pembelajaran tematik berwawasan 
multiple intellegence terhadap hasil belajar siswa kelompok eksperimen. Uji hipotesis menggunakan uji perbedaan dua rata-rata dengan uji pihak kanan.

Sedangkan indikator keberhasilan penelitian ini adalah 1) selisih nilai ratarata sebelum dan sesudah adanya penerapan pembelajaran tematik berwawasan multiple intellegence kelompok eksperimen lebih tinggi jika dibandingkan dengan kelompok kontrol, 2) Presentase peningkatan hasil belajar siswa sesudah dan sebelum pembelajaran dengan penerapan pembelajaran tematik berwawasan multiple intellegence kelompok eksperimen lebih tinggi jika dibandingkan dengan kelompok kontrol.

\section{HASIL DAN PEMBAHASAN Hasil Penelitian \\ 1. Hasil Pretest}

Sebelum kelompok kontrol dan eksperimen mendapatkan pembelajaran, dilakukan pretest untuk mengetahui bahwa kedua kelompok berawal dari kondisi yang sama. Nilai pretest dianalisis menggunakan uji keseimbangan menggunakan uji anava satu jalan meliputi uji normalitas populasi dan uji homogenitas variansi populasi.

Tabel 2. Rangkuman Hasil Uji Normalitas adanya normalitas atau tidak. Oleh karena itu, uji normalitas populasi ini dilakukan sebanyak dua kali, yakni masing-masing terhadap data hasil nilai pretest siswa pada kelas eksperimen dan kelas kontrol. Dengan taraf signifikansi 0,05 . Rangkuman hasil uji normalitas populasi menggunakan metode Lilliefors disajikan dalam Tabel berikut.

Sedangkan untuk uji homogenitas menggunakan metode Bartlett dengan $\chi^{2}$ obs 0,484 dengan $\chi^{2}$ $(\alpha, \mathrm{k}-1) \quad 3,8410$ sehingga $\mathrm{H}_{0}$ diterima. Untuk hasil uji keseimbangan terhadap data hasil nilai pretest, diperoleh nilai $\mathrm{F}_{0,05 ; 1 ; 54}$ sebesar 1,01 dengan $\mathrm{DK}=\{\mathrm{F} \mid \mathrm{F}>4,00\} \quad$ sehingga $F_{o b s}$ tidak terletak pada daerah kritik. Hal ini berarti bahwa pada taraf signifikansi $0,05 \mathrm{H}_{0}$ diterima. Dengan demikian, diperoleh kesimpulan bahwa populasi pada kelas eksperimen dankelas kontrol mempunyai kemampuan awal yang sama.

\section{Hasil Postest}

Sesudah penerapan pembelajaran tematik berwawasan multiple intellgence dalam upaya membentuk karakter siswa dan pendekatan konvensional, selanjutnya dilakukan pengukuran hasil belajar (posttest) untuk mengetahui kemampuan kognitif kedua kelas

\begin{tabular}{lcccc}
\hline \multicolumn{1}{c}{ Sumber } & $\mathbf{L}_{\mathbf{o b s}}$ & $\mathbf{T}_{\boldsymbol{a}, \mathbf{n}}$ & Keputusan & Kesimpulan \\
\hline $\begin{array}{l}\text { Kelompok pembelajaran } \\
\text { Tematik dengan wawasan } \\
\text { multiple intellegence (kelas } \\
\text { eksperimen) }\end{array}$ & 0,1143 & 0,1674 & $\mathrm{H}_{0}$ diterima & Normal \\
$\begin{array}{l}\text { Kelompok pembelajaran } \\
\text { Konvensional (kelas kontrol) }\end{array}$ & 0,1085 & 0,1674 & $\mathrm{H}_{0}$ diterima & Normal \\
\end{tabular}

Hasil uji normalitas diperoleh tersebut. Hasil postest pada kelas dari nilai pretest yang dilakukan sebelum eksperimen menunjukkan bahwa skor eksperimen dengan menggunakan tertinggi 100 dan skor terendah 86. Dari metode Lilliefors, untuk memperjelas perhitungan yang sudah dilakukan 
didapatkan hasil mean $(96,7)$, varians $(14,9)$ dan standar deviasi $(3,8)$. Sedangkan pada kelas kontrol menunjukkan skor tertinggi 100 dan skor terendah 75. Dengan hasil perhitungan mean $(89,9)$, varians $(39,2)$ dan standar deviasi $(6,2)$.

Berdasarkan perhitungan data postest selanjutnya data tersebut dianalisis uji normalitas dan uji kesamaan dua varian. Hasil uji normalitass didapatkan $\chi^{2}$ hitung untuk kelompok eksperimen sebesar 7,79 dan $\chi^{2} \quad$ hitung untuk kelompok control sebesar 1,53dengan $\chi^{2}$ tabel 7,81. Sehingga jelas bahwa $\chi^{2}$ hitung $<\chi^{2}$ tabel, maka data kedua kelompok berdistribusi normal, sedangkan hasil uji kesamaan dua varian menunjukkan bahwa $F_{\text {hitung }} 1,73$ sedangkan $F_{\text {tabel }}$ dengan kesalahan 5\% adalah 1,9 jika $\mathrm{F}_{\text {hitung }}<$ pada $\mathrm{F}_{\text {tabel }}$ maka berarti kedua kelompok mempunyai varians yang tidak berbeda secara signifikan. Hal ini menunjukkan bahwa data yang digunakan telah memenuhi syarat untuk digunakan dalam perhitungan uji perbedaan dua rata-rata (uji-t).

Hasil analisis dari nilai rata-rata posttest kedua kelompok yaitu kelompok kontrol dan kelompok eksperimen telah menunjukkan adanya perbedaan. Meskipun demikian, hal ini belum sepenuhnya menjawab hipotesis yang diajukan. Untuk mengetahui adanya perbedaan hasil belajar antara kelas eksperimen dan kelas kontrol, sekaligus untuk mengetahui pengaruh penerapan pembelajaran tematik berwawasan multiple intellegence terhadap hasil belajar pada kelompok eksperimen maka dilakukan uji perbedaan dua rata-rata (uji-t). Hasil uji perbedaan rata-rata yang menunjukkan bahwa kelompok kontrol dengan kelas eksperimen memiliki perbedaan rata-rata yang signifikan dengan thitung 5,58 $>\mathrm{t}$ tabel 1,67. Hal ini menunjukkan bahwa kelompok kontrol dengan kelas eksperimen memiliki perbedaan rata-rata yang signifikan. Adanya perbedaan rata-rata antara kelompok kontrol dengan kelompok eksperimen menunjukkan bahwa penerapan pembelajaran tematik berwawasan multiple intellegence mempengaruhi hasil belajar siswa kelompok eksperimen pada tema kegiatanku.Adanya perbedaan rata-rata antara kelompok kontrol dengan kelompok eksperimen menunjukkan bahwa penerapan pembelajaran tematik berwawasan multiple intellegence mempengaruhi hasil belajar siswa kelompok eksperimen pada tema kegiatanku.

Selain itu hasil perhitungan selisih nilai rata-rata pada kelompok eksperimen sebesar 32,50 lebih tinggi daripada kelompok kontrol 29,18. Peningkatan hasil belajar sebelum dan sesudah pembelajaran antara kelompok kontrol dan kelompok eksperimen 32\% dan 34\%. Hal ini menunjukkan peningkatan hasil belajar kelompok eksperimen lebih tinggi dibandingkan dengan kelompok kontrol. Hal ini disebabkan adanya perbedaan proses pembelajaran yang dilakukan pada kelompok kontrol dengan kelompok eksperimen. Pada kelompok eksperimen menggunakan pembelajaran tematik berwawasan multiple intellegence sedangkan kelompok kontrol hanya menggunakan pembelajaran tematik saja dengan model pembelajaran langsung.

\section{PEMBAHASAN}

Penelitian ini menggunakan dua sampel kelas yang memiliki karakteristik sama. Dua kelas tersebut diberi perlakuan yang sedikit berbeda yaitu satu sampel sebagai kelompok eksperimen dengan menerapkan pembelajaran tematik berwawasan 
multiple intellegence sedangkan kelompok kontrol hanya menerapkan pembelajaran tematik. Pada kelas satu memang diterapkan pembelajaran tematik di semua kelas. Hal ini didasari bahwa perkembangan anak bersifat sistematis, progresif, dan berkesinambungan. Pada anak usia sekolah dasar kelas satu tahapan fase belajarnya masih belum bisa berpikir secara terpisah-pisah atau masih secara holistik. Oleh karena itu pembelajaran tematik dirancang dengan tema sebagai wadah mengenalkan berbagai konsep untuk mengenal dirinya dan lingkungan sekitarnya. Tema dipilih dan dikembangkan dari hal-hal yang paling dekat dengan anak, sederhana, serta menarik minat dan menyenangkan.

Hasil belajar siswa yang diamati dalam penelitian ini meliputi tiga ranah kognitif, afektif dan psikomotorik karena pada hakikatnya hasil belajar merupakan perubahan tingkah laku yang mencakup bidang kognitif, afektif dan psikomotorik. Pada ranah afektif yang diamati oleh peneliti berupa penanaman nilai karakter siswa melalui proses pembelajaran.

Dari hasil penelitian menunjukkan bahwa nilai pretest pada kelompok kontrol maupun kelompok eksperimen tidak berbeda secara signifikan

Pemberian proses pembelajaran yang berbeda pada penerapan pembelajaran tematik yang berwawasana multiple intellegence ternyata memberikan hasil belajar siswa yang berbeda. Pada hasil analisis nilai posttestmenunjukkan bahwa hasil belajar siswa pada ranah kognitif kelompok eksperimen lebih baik daripada kelompok kontrol. Kedua kelompok sama-sama mengalami peningkatan hasil belajar, namun pada kelompok eksperimen mengalami persentase yang lebih tinggi dibanding dengan kelompok kontrol. Yaitu pada kelompok eksperimen nilai rata-rata 96,68 sedang kelompok kontrol 89,93.

Pelaksanaan pembelajaran tematik berwawasan multiple intellegence disesuaikan dengan kecerdasan yang dimiliki pada anak. Pada dasarnya siswa memiliki semua kedelapan kecerdasan yang sudah dijelaskan diatas akan tetapi kadarnya berbeda-beda atau yang menonjol hanya salah satu kecerdasan saja. Dalam penelitian ini memfokuskan dalam lima kecerdasan yaitu kecerdasan verbal/linguistik, visual, kinestetik, musikal, dan matematis yang ditonjolkan, meskipun pada dasarnya semua kecerdasan bekerjasama dalam satu kesatuan utuh dan terpadu. Kecerdasan seorang siswa mempengaruhi pola belajar dan kualitas hasil belajar siswa.

Implementasi pembelajaran tematik berwawasan multiple intellegence siswa melakukan berbagai kegiatan dalam proses pembelajaran meliputi pembelajaran dengan menggunakan puzzle tubuh manusia. Dalam kegiatan ini siswa secara berkelompok membongkar puzzle yang telah disediakan oleh guru kemudian memasangkannya kembali dengan baik serta mampu menyebutkan bagianbagian anggota tubuh yang ditunjuk oleh guru. Pada proses ini yang dikembangkan adalah kecerdasan visualspasial.

Selanjutnya dalam kegiatan pembelajaran guru juga mengembangkan kecerdasan linguistik melalui penunjukkan siswa untuk mendeskripsikan gambar (berupa suasana siang hari dan malam hari) yang sudah ditempel oleh guru didepan kelas. Siswa menjelaskan hal yang dia ketahui sesuai pengalaman yang dia punya didepan kelas. Pada kegiatan ini guru sekaligus bisa memulai penanamkan nilai karakter rasa ingin tahu serta mandiri. 
Setiap pertemuan, guru mengawali proses pembelajaran dengan bernyanyi dan beryel-yel untuk membangkitkan semangat belajar siswa sekaligus mengembangkan kecerdasan musikal. Contohnya dalam pertemuan yang kedua ketika pembahasan tema kegiatanku sampai pada bahsan tentang aktivitasku aatau kegiatanku pada pagi hari. Siswa diajak bernyanyi bersama-sama dengan lirik lagu bangun tidur.

Kecerdasan

dikembangkan dengan menghitung beberapa gambar bunga yang ada dalam gambar suasana pagi hari. Hal ini juga merangsang kecerdaan kinestetik dengan cara bekerja kelompok, kemudian kunjungan antar kelompok serta melatih nilai karakter tanggung jawab pada setiap siswa.

Berbagai kecerdasan yang dikembangkan dalam penelitian ini masih dapat dikembangkan dengan berbagai kegiatan lain. Pendapat ini dikuatkan dengan konsep dari Gadner (2003) bahwa kecerdasan seseorang itu berkembang, dan tidak statis. Kecerdasan seseorang lebih berkaitan dengan kebiasaan yaitu perilaku yang diulang-ulang. Hal ini juga selaras dengan pembentukan karakter yang dapat dilakukan dengan pembiasaan atau pengulangan. Seperti yang telah diungkapkan oleh Sumarmo (2012) bahwa pembentukan karakter dapat dilakukan dengan cara (1) pemberian pemahaman yang benar tentang pendidikan karakter; (2) pembiasaan; (3) contoh atau teladan dan (4) pembelajaran secara integral.

Upaya penerapan pembelajaran tematik berwawasan multiple intellegence memberikan pengalaman belajar yang lebih menyenangkan bagi siswa. Siswa tidak merasa bosan dalam proses pembelajaran karena siswa belajar dengan cara menemukan teori sendiri melalui aktivitas yang nyata dalam kehidupan sehari-hari sesuai dengan kecerdasan yang menonjol pada diri siswa. Hal ini diperkuat dengan pendapat Susanto (2006) bahwa penerapan pembelajaran dengan multiple intellegences tidak memaksakan anak untuk hanya menguasai kemampuan matematika dan bahasa, tetapi mereka pun dapat membimbing dan mengarahkan anaknya sesuai dengan keunikannya masing-masing. Selain itu proses memperoleh pengalaman pada pembelajaran tematik berwawasan multiple intellegence mengacu pada proses belajar aktif. Sukandi (2003) mengungkapkan bahwa siswa akan belajar melalui pengalaman, beinteraksi dengan berbagai aneka sumber belajar, berkomunikasi, dan berefleksi. Belajar melalui pengalaman, siswa belajar secara langsung dengan obyek yang dipelajari dan melibatkan banyak indra. Belajar akan bermakna jika siswa berinteraksi dengan orang lain. Berkomunikasi maksudnya, siswa menyampaikan gagasan, pendapat, pikiran, perasaaan, baik secara lisan maupun tulisan. Refleksi maksudnya, siswa diberi kesempatan apakah gagasan, pendapat, pikiran, perasaan, yang telah disampaikan dalam suatu kesempatan sudah tepat dan benar.

Karakter yang terbentuk pada penelitian ini meliputi nilai karakter demokratis, tanggung jawab, mandiri dan rasa ingin tahu. Sesuai dengan hasil pengamatan pada saat proses pembelajaran karakter siswa sudah mulai telihat sampai sdah mulai membudaya. Hal ini dikarenakan di SD IT Al Islam dalam setiap kegiatan pembelajaran maupun diluar pembelajaran pendidikan karakter sangat didukung oleh civitas sekolah.

Penerapan multiple intellegence pada pembelajaran tematik dalam upaya membentuk karakter siswa sebenarnya bukan hanya tugas atau tanggung jawab 
guru dan kepala sekolah saja, akan tetapi pihak orang tua pun perlu dilibatkan. Kita harus bersinergi dengan pihak orang tua. Orang tua pun memiliki andil dalam menentukan cara belajar anaknya. Masih banyak orang tua yang memiliki pola pikir tradisional dalam memandang kemampuan yang harus dicapai oleh anaknya. Atau penerapan karakter yang tidak sinkron dengan yang sudah diterapkan dalam pembelajaran di sekolah. Jadi untuk proses pembelajaran tematik berwawasan multiple intellegence sebagai upaya membentuk karakter siswa tidak akan berhasil atau berpengaruh ketika proses belajar mengajar tidak didukung oleh pihak sekolah maupun oleh pihak keluarga.

\section{KESIMPULAN}

Penerapan pembelajaran tematik berwawasan multiple intellegence dalam upaya membentuk karakter siswa di SD
IT Al Islam Kudus dapat dilaksanakan dengan dengan mengoptimalkan kecerdasan yang dimiliki oleh siswa sesuai dengan proses pembelajaran yang aktif, kreatif, efektif dan menyenangkan.

Selisih nilai rata-rata pada kelompok eksperimen sebesar 32,50 lebih tinggi daripada kelompok kontrol 29,18. Peningkatan hasil belajar sebelum dan sesudah pembelajaran antara kelompok kontrol dan kelompok eksperimen 32\% dan $34 \%$.

Karakter siswa dalam proses pembelajaran tematik berwawasan multiple intellegence dalam upaya membentuk karakter siswa kelas I SD Islam Terpadu Al Islam Kudus mulai terlihat sampai sudah membudaya. Karakter yang teramati meliputi karakter mandiri, tanggung jawab, rasa ingin tahu dan demokratis.

\section{RUJUKAN}

Arikunto S. 2002. Dasar-dasar Evaluasi Pendidikan (Edisi Revisi). Jakarta: BumiAksara.

Armstrong, Thomas. 2013. Kecerdasan Multipel di dalam Kelas. Jakarta: Indeks.

Budiningsih, Asri. 2005. Belajar dan Pembelajaran. Jakarta: Rineka Cipta.

Budiyono.2003. Metodologi Penelitian Pendidikan. Surakarta: UNS Press.

2011. Penilaian Hasil Belajar. Program Pascasarjana. UNS Press.

Gardner, H. 2006. Multiple Intellegences: New horizon in theory and practice. New York: Basic Books.

Gardner, H. 2003. Keceerdasan Majemuk (Multiple Intellegences): Teori dalam Praktek. Batam: Interaksara.

Kwartolo. 2012. Multiple Intellegences dan Implementasinya dalam Taksonomi Bloom. Pendidikan Penabur 5 (4) : 29-42.

Sudrajat, A. 2010. Tentang Pendidikan Karakter. Tersedia Online: http://akhmadsudrajat.wordpress.com/2010/08/20 (di unduh 30 September 2012). 
Sukandi, U. 2003. Belajar Aktif dan Terpadu. Surabaya: Duta Graha Pustaka

Sumiatun. 2006. Abstrak Skripsi. Model pembelajaran tematik berbasis multiple intellegence di kelas I SD Muhammadiyah 9 "Panglima Sudirman" Kecamatan Klojen Kota Malang. (diunduh 15 Februari 2013).

Sutirjo dan Sri Istuti Mamik. (2005). Tematik: Pembelajaran Efektif dalam Kurikulum 2004. Malang: Bayumedia Publishing.

Sudjana. 2002. Metode Statistika. Bandung: Tarsito.

Sukmadinata NS. 2005. Metode Penelitian Pendidikan. Bandung: Remaja Rosdakarya.

Susanto, H. 2006. Penerapan Multiple Intellegences dalam Sistem Pembelajaran. Pendidikan Penabur 4 (4) : 67-75.

Sugiharti. 2005. Penerapan Multiple Intellegences dalam Pembelajaran Fisika. Pendidikan Penabur 5 (4) : 29-42.

Trianto. 2011. Model Pembelajaran Terpadu dalam Teori dan Praktek. Jakarta: Prestasi Pustaka.

Trianto. 2012. Mengembangkan Model Pembelajaran Tematik. Jakarta. Prestasi Pustaka Publisher. 